\title{
PRE SERVICE TEACHERS' PERCEPTION ON THE IMPLEMENTATION OF PROJECT BASED LEARNING IN MATHEMATIC CLASS
}

\author{
Marah Doly Nasution', Ahmad*2, Zulkifley Mohamed ${ }^{3}$ \\ ${ }^{1}$ Universitas Muhammadiyah Sumatera Utara, Indonesia \\ ${ }^{2}$ Universitas Muhammadiyah Purwokerto, Indonesia \\ ${ }^{3}$ Sultan Idris Education University, Malaysia
}

\begin{tabular}{l}
\hline Article Info \\
\hline Article history: \\
Received Nov 6, 2020 \\
Revised Jan 16, 2021 \\
Accepted Jan 18, 2021 \\
\hline
\end{tabular}

\section{Keywords:}

Mathematics Education, Pre Service Teacher, Project Based Learning

\begin{abstract}
Project-based learning is one of the 21st-century methods that can increase the students' ability to have useful competence in their knowledge, especially in learning mathematic. Hence, the teachers' perception of the implementation of PBL is essential to know. The purpose of this study was to determine student perceptions about the application of project-based learning models. This research is a survey research with a quantitative descriptive approach. The samples used in this study amounted to 63 students of the sixth semester in the Department of Mathematical Education, Muhammadiyah University North Sumatra. The data collection technique used a questionnaire. The data analysis technique consists of quantitative analysis techniques with a statistical approach. The results of this study indicate that: (1) the students' perceptions of the interaction aspects of students and teachers are in the very good category with a mean score of $85.32 \%$. (2) Students' perceptions of motivation / increasing student interest in learning are in the very high category, with an average score of $85.53 \%$. (3) Students' perceptions on the competency aspect of understanding subject matter are in the very good category with an average score of $85.48 \%$. (4) Students' perceptions of the competency aspects of critical, effective, and efficient thinking are in the category of strongly agree with a mean score of $82.62 \%$. (5) Students' perceptions of good time management competence are in the good category with an average score of $79.10 \%$. (6) Students' perceptions of good student learning outcomes are in the very good category, with a mean score of $82.67 \%$. (7) Students' perceptions of the learning model's conformity aspect with subject characteristics are in the very high category with a mean score of $84.05 \%$.
\end{abstract}

Copyright (C) 2021 IKIP Siliwangi. All rights reserved.

\section{Corresponding Author:}

Ahmad,

Department of Mathematics Education

Universitas Muhammadiyah Purwokerto,

Jl. KH. Ahmad Dahlan, Kembaran, Banyumas, Central Java 53182, Indonesia

Email:ahmad@ump.ac.id

\section{How to Cite:}

Nasution, M. D., Ahmad, A., \& Mohamed, Z. (2021). Pre service teachers' perception on the implementation of project based learning in mathematic class. Infinity, 10(1), 109-120.

\section{INTRODUCTION}

Teachers are expected to be able to choose and use learning strategies in accordance with the material to be delivered (English \& Kitsantas, 2013). Every learning strategy has 
strengths and weaknesses seen from various angles, but in essence any learning strategies, method or model used must have clear objectives to be achieved (Kurzel \& Rath, 2007). Because students have very heterogeneous interests, ideally a teacher should use a multimethod, that is, varying the use of the learning model used in the classroom. This is intended to avoid boredom experienced by students (Tamim \& Grant, 2013). In this process, students use all their basic abilities and knowledges to obtain information and the learning outcomes they get. Students try to find out and solve solutions to any existing problems (Amamou \& Cheniti-Belcadhi, 2018). So that students get experience and knowledge that are truly meaningful, not only learning outcomes in terms of values.

Project-Based Learning (PBL) is a learning model that is conceptualized on a process, timed, problem-focused, meaningful learning unit by integrating concepts from a number of components of knowledge, discipline and collaborative learning activities. So that in its implementation the teachers act as a facilitator whose task is to help provide experience for students in designing problem solving related to the subject matter (Efstratia, 2014).

Students are expected to be able to interact with teachers and study groups to find solutions of the problems (van Rooij, 2009). PBL contains project-based complex tasks based on the questions and problems that are very challenging, and requires students to design, solve problems, make decisions, carry out investigative activities, well as provide the opportunity for students to work independently. The goal is that students have independence in completing the tasks they face (Barron et al., 1998).

In the implementation of learning, PBL teachers pose problems in the form of sheets Student Activities then students carry out activities to complete problems and teachers oversee student performance (Amamou \& Cheniti-Belcadhi, 2018). When finished, one of the students representing the group presented the results of the discussion in front of the group then asked each other questions. The teacher leads the class discussion.

This shows that with the PBL model students can develop conceptual understanding, procedural skills, ways of thinking of launching a related problem so that they can understand the problem setting and find out the next steps to take through discussion (Sart, 2014). As a result of the discussion, students will become more skilled at using ideas and techniques that produce experiences of the problems at hand (Anazifa \& Djukri, 2017).

This research tried to explore more deeply the teachers' perception about using PBL. The deep analysis by exploring the previous research and the current literature review enrich the novelty of this research. The reasons in conducting this research know the teacher's perception on PBL model will give a new paradigm on how to use PBL in teaching and learning process, especially in learning mathematic, thus the possession of this research is very important for futher research the same topic.

Based on the considerations of the thoughts and problems, the researcher took the title "Pre service teachers' perception on the implementation of Project based Learning in mathematic class".

\section{METHOD}

The type of research used is a survey with a quantitative descriptive approach, where the phenomena to be studied are events that have passed or are ongoing (Design-Based Research Collective, 2003). The procedure of the research follows the scientific model of descriptive analysis in which it is conducted using some stages, namely: deciding the best model of research, selecting the suitable respondents, creating and validating the instrument and doing the scientific analysis methods to guarantee the output of this research. This type selected for this study intends to reveal how the process of applying and perceptions of students about the model of project-based learning (project-based learning) in mathematics 
samples used in this study amounted to 63 respondents student 6th semester Mathematics Education, University of Muhammadiyah Sumatra Utara. In collecting information about student perceptions, researchers used a questionnaire in the form of a closed questionnaire with alternative answers given to the indicators, namely Strongly Agree, Agree, Disagree), and Strongly Disagree. There are 7 indicators used to measure student perceptions with a total of 30 questions (see Table 1).

Table 1. Research instrument grid of project-based learning in mathematics

\begin{tabular}{|c|c|c|}
\hline Indicator & Item Number & Total Number \\
\hline 1. Interaction aspects students and teachers & $1,2,3,4,5$ & 5 \\
\hline $\begin{array}{l}\text { 2. Ability to motivate / increase interest } \\
\text { student learning }\end{array}$ & $6,7,8,9$ & 4 \\
\hline 3. Understanding the subject matter & $10,11,12,13,14$ & 5 \\
\hline $\begin{array}{l}\text { 4. Emerging think critically, effectively and } \\
\text { efficiently }\end{array}$ & $15,16,17,18,19$ & 5 \\
\hline 5. Effective time management & $20,21,22$ & 3 \\
\hline 6. Student learning outcomes & $23,24,25$ & 3 \\
\hline $\begin{array}{l}\text { 7. The suitability of the application of the } \\
\text { learning model with subject characteristics }\end{array}$ & $26,27,28,29,30$ & 5 \\
\hline \multicolumn{2}{|c|}{ Number of Questions / Statements } & 30 \\
\hline
\end{tabular}

Descriptive statistical analysis, including mean price, standard deviation, median value, mode, range, highest score, lowest score and frequency distribution were used for each research variable / indicator.

\section{RESULTS AND DISCUSSION}

In this research, there are 7 indicators that can measure the success of implementing the project-based learning model. The following is an analysis of the results of research on student perceptions about the application of project-based learning in subjects (see Table 2).

Table 2. Results of analysis of students' perceptions

\begin{tabular}{lcc}
\hline \multicolumn{1}{c}{ Indicator } & Percentage & Category \\
\hline $\begin{array}{l}\text { Student Perceptions in terms of Student and teachers } \\
\text { Interaction Aspects }\end{array}$ & $85.32 \%$ & Very good \\
$\begin{array}{l}\text { Student Perceptions in terms of Motivation / } \\
\text { increase Student Learning Interest }\end{array}$ & $83.53 \%$ & Very good \\
$\begin{array}{l}\text { Perception of Subject matter } \\
\text { Student Perceptions are reviewed from Critical, } \\
\text { Effective and Efficient Thinking Competencies }\end{array}$ & $85.48 \%$ & Very high \\
\hline
\end{tabular}




\begin{tabular}{lcc}
\hline \multicolumn{1}{c}{ Indicator } & Percentage & Category \\
\hline $\begin{array}{l}\text { Perception of Students Judging from Good Time } \\
\text { Management Competence }\end{array}$ & $79.10 \%$ & Good \\
$\begin{array}{l}\text { Perception of Students Judging from results Good } \\
\text { Student Learning }\end{array}$ & $82.67 \%$ & Very good \\
$\begin{array}{l}\text { Student Perceptions About the Suitability of the } \\
\text { Application of Learning Models with Subject } \\
\text { Characteristics }\end{array}$ & $84.05 \%$ & Very high \\
\end{tabular}

Table 2 shows that: (1) students' perceptions of the aspects of student and teachers' interaction are in the very good category with an average score of $85.32 \%$; (2) Students' perceptions on the aspect of motivation / increasing student interest in learning are in the very high category with an average score of $85.53 \%$; (3) Students' perceptions on the competency aspect of understanding subject matter are in the very good category with an average score of $85.48 \%$; (4) Students' perceptions of the competency aspects of critical, effective and efficient thinking are in the category of strongly agree with a mean score of $82.62 \%$; (5) Students' perceptions of the aspects of good time management competence are in the good category with an average score of 79.10\%; (6) Students' perceptions on aspects of good student learning outcomes are in the very good category with a mean score of 82.67\%; (7) Students' perceptions on the conformity aspect of the learning model with subject characteristics are in the very high category with a mean score of $84.05 \%$.

\subsection{Student' perception in terms of student and teachers' interaction}

The results of data analysis on student perceptions about project-based learning models on the indicators of student and teachers' interaction aspects can be seen in the Table 3.

Table 3. Student Perception of student and teachers' interaction

\begin{tabular}{cccc}
\hline Ideal Score Interval & Frequency & \% & Category \\
\hline$>16.25$ & 35 & 55.56 & Very good \\
12.5 to 16.25 & 28 & 44.44 & Good \\
8.75 to 12.5 & 0 & 0 & Bad \\
$<8.75$ & 0 & 0 & Very Bad \\
\hline
\end{tabular}

Table 3 shows that there are 35 students $(55.56 \%)$ who are in the very good category, 28 students $(44.44 \%)$ are in the good category and there are no students who are in the sufficient and very bad category.

From the analysis of each question item of the indicators of student and teachers' interaction aspects which consist of 5 questions. The lowest mean score was 3.32, which is in question item number 1 with the question: "I feel more active in working on drawing assignments with a project-based learning model". About 5 the questions raised, only item number 1 has the lowest mean, but that does not mean intercourse students and faculty are located in the poor category. This is evidenced by the interaction between students and teachers on question items 2-5 still going very Good. So that it can support the deficiencies in item number 1 . 
Data obtained from questionnaires given to 63 respondents on indicators of the interaction of students and professors showed that the tendency of the average score (mean) of $17.06(85.32 \%)$ lies in the class interval $>16.25$ in the excellent category.

From the findings that have been explained, that students strongly agree with the application of the project-based learning model on the aspects of student and teachers' interaction (Mills \& Treagust, 2003). This is in accordance with the objectives of implementing the project-based learning model, namely to create a more active condition of student and teachers' interaction (Condliffe et al., 2017), so that in dealing with problems in carrying out assignments and subject matter can run smoothly. The teachers as a facilitator in this learning model can play a role, namely by knowing the progress of the learning activities that students carry out from the interaction process. It is stated that the learning method is a method used by teachers to establish relationships / interactions with students.

\subsection{Students' perception of the term motivation and learning interest}

The results of the data analysis, perceptions of students about project-based learning model on indicators of motivation / growing interest in learning of students (see Table 4).

Table 4. Students' perception in the term of motivation and learning interest

\begin{tabular}{cccc}
\hline Ideal Score Interval & Frequency & $\boldsymbol{\%}$ & Category \\
\hline$>13$ & 32 & 50.79 & Very high \\
10 to 13 & 31 & 49.21 & High \\
7 to 10 & 0 & 0 & Moderate \\
$<7$ & 0 & 0 & Low \\
\hline
\end{tabular}

Table 4 shows that there are 32 students $(50.79 \%)$ in the very high category, 31 students $(49.21 \%)$ in the high category and no students who are in the medium and low categories.

From the analysis of each question item of this indicator it can be seen that the lowest mean score was 3.21, which is in question item 9 with the question: "I don't feel tired in doing every assignment given by the teachers ". With these findings, this statement implies that students still feel tired in doing their Very Bad on work. This is influenced by the length of the meeting duration for each one-time meeting. And the number of each Very Bad on competency that must be achieved. However, of the 4 question items, there are weaknesses in question number 9 that can be overcome with questionable items 6-8, that students remain motivated, increase interest in learning and are enthusiastic in implementing project-based learning models in mathematics subjects.

Data obtained from questionnaires given to 63 respondents on indicators of motivation interest to learn the students showed that the tendency of the average score (mean) of $13.37(83.53 \%)$ lies in the class interval > 13 in the category are very high.

From the findings that have been explained, that students strongly agree with the application of the project-based learning model in mathematics in the aspect of motivation / increasing student interest in learning. This indicator itself is a development of the analysis of student characteristics in the planning process of the learning model. So that in its application, it can be known or can be determined by the learning model used which can motivate / increase student interest in learning. And with this project-based learning model, it has been proven that students can be motivated / increase their interest in learning. 


\subsection{Students' perception of the term of understanding subject matter}

The results of data analysis on students' perceptions about project-based learning models on the competency indicators of understanding the subject matter (see Table 5).

Table 5. Students' perception understanding subject matter

\begin{tabular}{cccc}
\hline Ideal Score Interval & Frequency & $\boldsymbol{\%}$ & Category \\
\hline$>16.25$ & 37 & 58.73 & Very good \\
12.5 to 16.25 & 24 & 38.10 & Good \\
8.75 to 12.5 & 2 & 3.17 & Bad \\
$<8.75$ & 0 & 0 & Very Bad \\
\hline
\end{tabular}

Table 5 show that, there are 37 students $(58.73 \%)$ who are in the very good category, 24 students $(38.10 \%)$ are in the good category and there are no students who are in the sufficient and poor category.

From the analysis of each question item of the competency indicator in understanding the subject matter which consists of 5 questions. Obtained the lowest average score (mean) of 3.32, which is in question item number 13 with the question: "From the application of the project-based learning model, I have come to understand the meaning of each line in the mathematical picture". This question item has a role as a form of deepening students in understanding the material from mathematics subjects. Overall, the existing data on the indicators of material understanding, students can be said to understand and understand the content of mathematical subject matter by applying the mathematics learning model. This is supported by data analysis on this indicator, there are no students who disagree and disagree with the application of the project-based learning model in mathematics.

Data obtained from questionnaires given to 63 respondents to the indicators of competence to understand the subject matter shows that the propensity score average (mean) of $17.10(83.48 \%)$ lies in the class interval $>16.25$ excellent category.

From the findings that have been explained, that students strongly agree with the application of the project-based learning model in mathematics in the aspects of understanding the subject matter. This indicator is intended to measure the extent to which students understand understanding of the material considering the purpose of implementing a project-based learning model is to provide a memorable learning experience for students. As the definition stated that Project Based Learning is a method that foster abstract, intellectual tasks to explore complex issues (Alacapinar, 2008). PBL is a learning approach that pays attention to understanding the subject matter. So that students are required to explore, assess, interpret and synthesize learning information in meaningful ways (McDonald, 2008).

\subsection{Students' perception of the term of critical, effective and efficient thinking competencies}

The results of data analysis on students' perceptions about project-based learning models on the indicators of competency in critical thinking, effective and efficient (see Table $6)$. 
Table 6. Student perception in terms of critical, effective and efficient thinking competencies

\begin{tabular}{cccc}
\hline Ideal Score Interval & Frequency & $\%$ & Category \\
\hline$>16.25$ & 31 & 49.21 & Very good \\
12.5 to 16.25 & 32 & 50.79 & Good \\
8.75 to 12.5 & 0 & 0 & Bad \\
$<8.75$ & 0 & 0 & Very Bad \\
\hline
\end{tabular}

Table 6 shows that there are 31 students $(49.21 \%)$ who are in the very good category, 32 students $(50.79 \%)$ are in the good category and there are no students who are in the sufficient and poor category.

From the analysis of each question item of the competency indicator to think critically, effectively and efficiently which consists of 5 questions. Obtained the lowest average score (mean) of 3.11, which is in the item question number 19 with the question: "The project-based learning model made me find new ideas to work on math picture assignments ". This statement means that students have not been able to find renewable ideas by doing math assignments. Even though the project-based learning model in its application requires students to develop student ideas to find new knowledge in dealing with the work they face. However, the other four statements have shown good results, namely students are able to think creatively, can find solutions to any existing problems, can apply their drawing assignments into existing assignment exercises and can explore the potential that exists in students.

Data obtained from questionnaires given to 63 respondents to the indicators of competence critical thinking, effective and efficient show that the propensity score average (mean) of $16.52(82.62 \%)$ lies in the class interval $>16.25$ in the excellent category.

From the findings that have been explained, that students strongly agree with the application of the project-based learning model in mathematics subjects in the competency aspects of critical, effective and efficient thinking. So that in its application, the projectbased learning model has achieved self-development potential. This shows that the problems given by educators as a source of learning can train students to think and develop their potential and personality (Harisman et al., 2020; Hidayat \& Sariningsih, 2020; Putra et al., 2020; Widodo et al., 2020).

\subsection{Students' perception of the term of time management}

The results of data analysis on student perceptions about project-based learning models on indicators of time management competence are good (see Table 7).

Table 7. Student perceptions in terms of time management

\begin{tabular}{cccc}
\hline Ideal Score Interval & Frequency & \% & Category \\
\hline$>9.75$ & 35 & 55.56 & Very good \\
7.5 to 9.75 & 19 & 30.16 & Good \\
5.25 to 7.5 & 9 & 14.29 & Bad \\
$<5.25$ & 0 & 0 & Very Bad \\
\hline
\end{tabular}


Table 7 shows that there are 35 students $(55.56 \%)$ who are in the very good category, 19 students (30.16\%) are in the good category, 9 students (14.29\%) are in the sufficient category and there are no students who are in the poor category.

From the analysis of each question item on the indicator of time management competence Good which consists of 3 questions. The lowest mean score was 2.98, which is in the item question number 21 with the question: "I fill my spare time at home by doing math assignments". This statement has the lowest average score among the statements in the questionnaire regarding the application of the project-based learning model. This can happen because of the duration of the class meeting the students feel that they have had Bad, because in one face-to-face duration the duration lasts 10 Very Bad for hours. This means that from morning class hours to completion, students are faced with one subject. This is what makes students sometimes feel bored and bored. Therefore, the teachers applies a project-based learning model to overcome this problem. Given this learning model, students are given the freedom to think and learn while adhering to the learning objectives.

Data obtained from questionnaires given to 63 respondents at the time of management competency indicators demonstrated that the tendency of the average score (mean) of $9.49(79.10 \%)$ lies in the class interval $7.5-9.75$ in both categories.

From the findings that have been explained, it shows that students agree with the application of the project-based learning model in mathematics for the competency aspects of time management Good. The data show that students only agree and do not really agree, this is because the duration of studying at school is too long and students tend to feel bored. From this indicator, it can be measured that students work on mathematics only during class meetings. So, in this aspect needs more attention when considering that the project-based learning model has the goal of making students more independent in doing tasks including managing study time students with good (Scarbrough, Bresnen, et al., 2004).

\subsection{Students' perception of the term learning outcomes}

The results of data analysis on student perceptions about project-based learning models on indicators of student learning outcomes (see Table 8).

Table 8. Students' perception in the term of learning outcomes

\begin{tabular}{cccc}
\hline Ideal Score Interval & Frequency & \% & Category \\
\hline$>9.75$ & 39 & 61.90 & Very good \\
7.5 to 9.75 & 20 & 31.75 & Good \\
5.25 to 7.5 & 4 & 6.35 & Bad \\
$<5.25$ & 0 & 0 & Very Bad \\
\hline
\end{tabular}

Table 8 show that there are 39 students $(61.90 \%)$ who are in the very good category, 20 students $(31.75 \%)$ are in the good category, 4 students $(6.35 \%)$ are in the sufficient category and there are no students who are in the poor category.

From the analysis of each question item of the indicators of student learning outcomes which consist of 3 questions. Obtained the lowest average score (mean) of 3.22, which is in question item 23 with the question: "I am satisfied with my score results". From this statement, there were 4 students who disagreed with the results of their learning scores. However, from the results of the evaluation conducted by the teachers, the overall student learning competency achievement has met the complete limit, namely with a minimum score of 75 . 
Data obtained from questionnaires given to 63 respondents on indicators of learning outcomes of students who demonstrated that the tendency of the average score (mean) of $9.92(82.67 \%)$ lies in the class interval $>9.75$ in the excellent category.

From the findings that have been explained, that students strongly agree with the application of project-based learning models in mathematics as seen from the aspect of good student learning outcomes. This is also corroborated by the results of the teacher competency evaluation. That all students reach the minimum completeness limit of 75 . So that in its application the project-based learning model has been said to be successful and has achieved the learning objectives.

\subsection{Students' perception of the term of Suitability of Learning Model Application with Subject Characteristics}

The results of data analysis on student perceptions about project-based learning models on indicators of suitability of the application of learning models with subject characteristics (see Table 9).

Table 9. Student perceptions in terms of suitability of learning model application with subject characteristics

\begin{tabular}{cccc}
\hline Ideal Score Interval & Frequency & \% & Category \\
\hline$>16.25$ & 33 & 52.38 & Very high \\
12.5 to 16.25 & 30 & $47.62 \%$ & High \\
8.75 to 12.5 & 0 & 0 & Moderate \\
$<8.75$ & 0 & 0 & Low \\
\hline
\end{tabular}

Table 9 shows that there are 33 students $(52.38 \%)$ who are in the very high category, 30 students $(47.62 \%)$ are in the high category and there are no students who are in the medium and low categories.

From the analysis of each question item on the indicator of the suitability of the application of the learning model with the characteristics of the subject which consists of 5 questions. The lowest mean score was 3.29, which is in question item number 27 with the question: "The application of project-based learning models makes mathematics more interesting". And item number 28 with the question: "The picture I am working on making my math assignment more real". From these two statements, it can be seen that students think that using a project-based learning model has not been able to make mathematics more interesting and make it real. However, that statement is on a small scale. So that it does not really affect the application of project-based learning models in mathematics subjects.

Data obtained from questionnaires given to 63 respondents in conformity indicator learning model application with the characteristics of the subjects showed that the tendency of the average score (mean) amounted to $16.81(84.05 \%)$ lies in the class interval $>16.25 \mathrm{in}$ very high category.

From the findings of the data that have been explained, that students strongly agree with the application of the project-based learning model in mathematics on the aspects of the suitability of the characteristics of the learning model with the subjects (Gary, 2015). So that the project-based learning model on the subject has achieved success. The learning model is successful if it includes 3 stages, namely, planning, implementation and evaluation. The third phase of the project-based learning model in the eyes of subjects of mathematics has gone Good and get a positive response from students (Scarbrough, Swan, et al., 2004). 


\section{CONCLUSION}

The results of this study indicate that: (1) the students' perceptions of the interaction aspects of students and lecturers are in the very good category with a mean score of $85.32 \%$. (2) Students' perceptions on the aspect of motivation / increasing student interest in learning are in the very high category with an average score of $85.53 \%$. (3) Students' perceptions on the competency aspect of understanding subject matter are in the very good category with an average score of $85.48 \%$. (4) Students' perceptions of the competency aspects of critical, effective and efficient thinking are in the category of strongly agree with a mean score of $82.62 \%$. (5) Students' perceptions of the aspects of good time management competence are in the good category with an average score of $79.10 \%$. (6) Students' perceptions on aspects of good student learning outcomes are in the very good category with a mean score of $82.67 \%$. (7) Students' perceptions on the conformity aspect of the learning model with subject characteristics are in the very high category with a mean score of $84.05 \%$.

\section{ACKNOWLEDGMENTS}

The authors would like to express my special thanks to University of Muhammadiyah North Sumatra, University of Muhammadiyah Purwokerto and University of Sultan Idris for supporting the facilities and finances to accomplish this paper.

\section{REFERENCES}

Alacapınar, F. (2008). Effectiveness of project-based learning. Eurasian Journal of Educational Research (EJER), 33, 17-34.

Amamou, S., \& Cheniti-Belcadhi, L. (2018). Tutoring in project-based learning. Procedia Computer Science, 126, 176-185. https://doi.org/10.1016/j.procs.2018.07.221

Anazifa, R. D., \& Djukri, D. (2017). Project-Based Learning and Problem-Based Learning: Are They Effective to Improve Student's Thinking Skills?. Jurnal Pendidikan IPA Indonesia, 6(2), 346-355. https://doi.org/10.15294/jpii.v6i2.11100

Barron, B. J., Schwartz, D. L., Vye, N. J., Moore, A., Petrosino, A., Zech, L., \& Bransford, J. D. (1998). Doing with understanding: Lessons from research on problem-and project-based learning. Journal of the learning sciences, 7(3-4), 271-311. https://doi.org/10.1080/10508406.1998.9672056

Condliffe, B., Quint, J., Visher, M. G., Bangser, M. R., Drohojowska, S., Saco, L., \& Nelson, E. (2017). Project-Based Learning: A Literature Review. New York: Mdrc, Building Knowledge to Improve Social Policy.

Design-Based Research Collective. (2003). Design-based research: An emerging paradigm for educational inquiry. Educational researcher, 32(1), 5-8. https://doi.org/10.3102/0013189X032001005

Efstratia, D. (2014). Experiential education through project based learning. Procedia-social and behavioral sciences, 152, 1256-1260. https://doi.org/10.1016/j.sbspro.2014.09.362

English, M. C., \& Kitsantas, A. (2013). Supporting student self-regulated learning in problem-and project-based learning. Interdisciplinary journal of problem-based learning, 7(2), 128-150. https://doi.org/10.7771/1541-5015.1339 
Gary, K. (2015). Project-based learning. Computer, 48(9), 98-100. https://doi.org/10.1109/MC.2015.268

Harisman, Y., Noto, M. S., \& Hidayat, W. (2020). Experience student background and their behavior in problem solving. Infinity Journal, 9(1), 59-68. https://doi.org/10.22460/infinity.v9i1.p59-68

Hidayat, W., \& Sariningsih, R. (2020). Profil Kemampuan Penalaran Kreatif Matematis Mahasiswa Calon Guru. Jurnal Elemen, 6(1), 108-127. http://doi.org/10.29408/jel.v6i1.1738

Kurzel, F., \& Rath, M. (2007). Project Based Learning and Learning Environments. Issues in Informing Science \& Information Technology, 4, 503-510. https://doi.org/10.28945/967

McDonald, B. (2008). Assessment for Learning in Project Based Learning. International Journal of Learning, 14(10), 15-28. https://doi.org/10.18848/14479494/cgp/v14i10/45493

Mills, J. E., \& Treagust, D. F. (2003). Engineering education-Is problem-based or projectbased learning the answer?. Australasian journal of engineering education, 3(2), 216.

Putra, B. Y. G., Rosita, N. T., \& Hidayat, W. (2020). Profile of mathematical representation ability of junior high school students in Indonesia. Journal of Physics: Conference Series, 1657(1), 012003. https://doi.org/10.1088/1742-6596/1657/1/012003

Sart, G. (2014). The effects of the development of metacognition on project-based learning. Procedia-Social and Behavioral Sciences, 152, 131-136. https://doi.org/10.1016/j.sbspro.2014.09.169

Scarbrough, H., Bresnen, M., Edelman, L. F., Laurent, S., Newell, S., \& Swan, J. (2004). The processes of project-based learning: An exploratory study. Management learning, 35(4), 491-506. https://doi.org/10.1177/1350507604048275

Scarbrough, H., Swan, J., Laurent, S., Bresnen, M., Edelman, L., \& Newell, S. (2004). Project-based learning and the role of learning boundaries. Organization studies, 25(9), 1579-1600. https://doi.org/10.1177/0170840604048001

Tamim, S. R., \& Grant, M. M. (2013). Definitions and uses: Case study of teachers implementing project-based learning. Interdisciplinary Journal of problem-based learning, 7(2), 72-101. https://doi.org/10.7771/1541-5015.1323

van Rooij, S. W. (2009). Scaffolding project-based learning with the project management body of knowledge (PMBOK®). Computers \& Education, 52(1), 210-219. https://doi.org/10.1016/j.compedu.2008.07.012

Widodo, S. A., Irfan, M., Trisniawati, T., Hidayat, W., Perbowo, K. S., Noto, M. S., \& Prahmana, R. C. I. (2020). Process of algebra problem-solving in formal student. Journal of Physics: Conference Series, 1657(1), 012092. https://doi.org/10.1088/1742-6596/1657/1/012092 
